\title{
SISTEM PENDUKUNG KEPUTUSAN KENAIKAN JABATAN DI PT. GEOSCIENCES INDONESIA SERVIS DENGAN METODE SIMPLE ADDITIVE WEIGHTING (SAW)
}

\author{
Dimas Argi Mairinaldy ${ }^{1}$, Lukman $^{2}$, Avini Nurazhimah Arfa ${ }^{3}$ \\ Program Studi Informatika, Universitas Indraprasta PGRI \\ dimasargim@gmail.com ${ }^{1}$
}

Submitted August 28, 2019; Revised September 23, 2019; Accepted November 10, 2019

\begin{abstract}
Abstrak
Penelitian ini bertujuan untuk menganalisis sistem pendukung keputusan dalam penentuan kenaikan jabatan kartawan, selain membuat para pengguna dapat memahami maksud dari sistem informasi ini. Metode penelitian yang digunakan untuk merancang kenaikan jabatan ini adalah dengan menggunakan metode Ground research, analisis data dan observasi untuk mendapatkan data yang lebih lengkap. Aplikasi ini dibangun dengan menggunakan pemrograman java dan database MySQL. Setelah merancang dan menganalisa Sistem Informasi kenaikan jabatan karyawan ini, maka penulis dapat menarik kesimpulan bahwa sistem pendukung keputusan yang dihasilkan mempermudah PT. Geosciences Indonesia Servis dalam menentukan karyawan yang layak naik jabatan dan dapat digunakan untuk mendapatkan informasi mengenai bagaimana untuk menjaga keamanan data yang sudah disimpan.
\end{abstract}

Kata Kunci : Sistem Pendukung Keputusan, Kenaikan Jabatan Karyawan,Simple Additive Weighting

\begin{abstract}
This study aims to analyze the decision support system in determining Kartawan promotions, in addition to making users able to understand the purpose of this information system. The research method used to design this promotion is to use the method of Ground research, data analysis and observation to obtain more complete data. This application was built using java programming and MySQL database. After designing and analyzing the Information System Program for employee promotions, the writer can draw the conclusion that employee promotions are not always developing, and the promotion program can be used to obtain information about how to maintain the security of data that has been stored. And also to provide enthusiasm for existing employees, building applications for promotion is very time-consuming so that the results can be satisfying
\end{abstract}

Key Words : Decision Support System, Promotion of Employee, Simple Additive Weighting

\section{PENDAHULUAN}

Sumber daya manusia merupakan salah satu bagian terpenting dalam tumbuh kembangnya perusahaan. Suatu perusahaan dapat berkembang dengan baik tentunnya dipengaruhi oleh kualitas sumber daya manusia, dalam hal ini adalah karyawan yang bekerja diperusahaan tersebut. Salah satu elemen penting dari upaya meningkatkan kualitas sumber daya manusia dinilai dari segi motivasi atau semangat kerja karyawan, bisa dilakukan dengan memberinya sebuah penghargaan atau dengan kenaikan jabatan.
Kenaikan jabatan merupakan hal yang sangat penting bagi perencanaan karir karyawan dan juga untuk meremajakan suatu posisi jabatan agar diduduki oleh seseorang yang mempunyai kriteriakriteria yang cocok untuk menempati suatu jabatan yang diusulkan [6].

Sistem pendukung keputusan atau DSS (Decision Support System) merupakan salah satu jenis sistem aplikasi yang sangat terkenal dikalangan manajemen organisasi. DSS (Decision Support System) dirancang untuk membantu manajemen dalam proses 
pengambilan keputusan serta dapat meningkatkan proses dan kualitas hasil pengambilan keputusan. Secara garis besar DSS (Decision Support System) dibangun oleh tiga komponen utama yaitu database, model base, software system[5]. Sistem database berisi kumpulan dari semua data bisnis yang dimiliki oleh perusahaan, baik yang berasal dari transaksi sehari-sehari maupun data dasar (master file).

Pengambilan atau membuat keputusan adalah suatu proses yang dilaksanakan orang berdasarkan pengetahuan dan informasi yang ada padanya pada saat tersebut dengan harapan bahwa sesuatu akan terjadi [4]. Keputusan dapat diambil dari alternatif-alternatif dari keputusan yang ada. Alternatif keputusan tersebut dapat dilakukan dengan adanya informasi yang diolah dan disajikan dengan dukungan sistem penunjang keputusan. Adapun informasi terbentuk dari adanya data yang terdiri dari bilangan yang tersusun, diolah dan disajikan.

Pembangunan Sistem aplikasi ini dengan menggunakan Java, dan menggunakan Netbean sebagai IDE, karna Netbean merupakan salah satu IDE yang dikembangkan dengan bahasa pemrograman java[7], dan mempunyai ruang lingkup pemrograman yang terintegrasi dalam suatu perangkat lunak yang di dalamnya menyediakan pembangunan pemrograman GUI, compiler, dan interpreter.

Database yang digunakan dalam aplikasi ini adalah MySQL dimana database ini merupakan sistem manajemen basis data SQL yang sangat terkenal dan bersifat Open Source[2], dan bisa dikatakan lebih unggul dibandingkan dengan database server lainnya dalam Query data.

\section{Simple Additive Weigting Method} merupakan salah satu metode yang dapat digunakan untuk menyelesaikan MADM (Multi atribut decision making), MADM merupakan model dari MCDM (Multiple criteria decision making), MCDM sendiri adalah suatu metode pengambilan keputusan untuk menetapkan alternatif terbaik dari sejumlah alternatif berdasarkan beberapa kriteria tertentu. Konsep dasar metode ini adalah mencari penjumlahan terbobot dari rating kinerja pada setiap alternatif pada semua atribut. Metode ini membutuhkan proses normalisasi matriks keputusan (X) ke suatu skala yang dapat diperbandingkan dengan semua rating alternatif yang ada [3].

Adapun tujuan dari penelitian ini adalah untuk mengimplementasikan Simple Additive Weighting (SAW) kedalam bagian dari sistem pendukung keputusan (DSS) dalam menentukan karyawan yang layak mendapat kenaikan jabatan. Penelitian ini dilakukan untuk membuat aplikasi pendukung keputusan pada PT.Geosciences Indonesia Servis dengan menggunakan metode Simple Additive Weighting (SAW). Hasil akhir yang digunakan sebagai acuan pengambilan keputusan akan diurutkan dan kemudian pengambilan keputusan dapat mengambil data beberapa karyawan dengan nilai yang tertinggi sesuai dengan kebijakan perusahaan. Dari hasil pengolahan data dan perhitungan yang didapat, pengguna metode ini diharakan dapat membantu keputusan dalam menentukan calon karyawan yang berhak mendapat kenaikan atau promosi jabatan dengan lebih cepat dan akurat.

\section{METODE PENELITIAN}

Penelitian tahap awal dilakukan berdasarkan data yang telah diperoleh melalui tahapan wawancara, observasi dan studi pustaka untuk mendapatkan kebutuhan sistem yang akan digunakan untuk mencari solusi dalam masalah yang tepat. Metode perhitungan yang digunakan adalah Simple Additive Weighting (SAW), yaitu dengan mencari penjumlahan terbobot dari rating kinerja setiap 
alternative yang ada pada semua atribut, Metode perhitungan SAW ini membutuhkan proses normalisasi matrix keputusan (X) ke suatu skala yang dapat diperbandingkan dengan semua rating alternative yang ada.

$r_{i j}= \begin{cases}\frac{x_{i j}}{\operatorname{MAX}_{i} X_{i j}} & \text { Jika } j \text { adalah atribut Keuntungan (benefit) } \\ \frac{\operatorname{MIN}_{i} X_{i j}}{X_{i j}} & \text { Jika j adalah atribut Biaya (Cost) }\end{cases}$

dimana :

$\mathrm{r}_{\mathrm{ij}} \quad=$ nilai ratig kinerja ternormalisasi

$\mathrm{X}=$ nilai atribut yang dimiliki setiap kriteria ij

Max Xij = nilai terbesar dari kriteria ij

Min Xij = nilai terkecil dari setiap kinerja

Benefit $=$ jika nilai terbesar adalah terbaik

Cost $=$ jika nilai terkecil adalah terbaik

Tabel 1. Kategori Benefit dan Cost Kenaikan Jabatan

\begin{tabular}{|c|c|c|c|}
\hline No & Kriteria & Kategori & Keterangan \\
\hline 1. & Gaji & - & $\begin{array}{l}\text { Semakin kecil gaji, } \\
\text { maka semakin besar } \\
\text { peluang }\end{array}$ \\
\hline 2. & Absensi & + & $\begin{array}{l}\text { Semakin sering absen } \\
\text { masuk maka semakin } \\
\text { besar peluang }\end{array}$ \\
\hline 3. & $\begin{array}{c}\text { Kedisipli } \\
\text { nan }\end{array}$ & + & $\begin{array}{l}\text { Semakin tinggi nilai } \\
\text { rating kedisiplinan maka } \\
\text { makin besar peluang }\end{array}$ \\
\hline 4 & $\begin{array}{c}\text { Kejujura } \\
\mathrm{n}\end{array}$ & + & $\begin{array}{l}\text { Semakin tinggi nilai } \\
\text { rating kejujuran maka } \\
\text { makin besar peluang }\end{array}$ \\
\hline 5 & Inovatif & + & $\begin{array}{l}\text { Semakin tinggi nilai } \\
\text { rating inovatif maka } \\
\text { makin besar peluang }\end{array}$ \\
\hline
\end{tabular}

Dimana rij adalah rating kinerja ternormalisasi dari alternative $\mathrm{A}$, pada atribut $\mathrm{Cj} ; \mathrm{i}=1,2, \ldots, \mathrm{m}$ dan $\mathrm{j}=1,2, \ldots, \mathrm{n}$. Nilai presensi untuk setiap alternative (Vi) diberikan sebagai :

$$
\mathrm{V}_{\mathrm{i}}=\sum_{\mathrm{j}=1}^{\mathrm{n}} \mathrm{W}_{\mathrm{j}} \mathrm{r}_{\mathrm{ij}}
$$

dimana :

$V_{\mathrm{i}} \quad=$ ranking untuk setiap alternatif

$W_{\mathrm{j}} \quad=$ nilai bobot dari setiap kriteria

$\mathrm{r}_{\mathrm{ij}} \quad=$ nilai rating kerja ternormalisasi

Nilai Vi yang lebih besar mengindikasikan bahwa alternative $A_{i}$, lebih terpilih[1].

\section{HASIL DAN PEMBAHASAN Penentuan dari Kriteria diterapkan}

Beberapa aspek kriteria sistem penilaian kinerja karyawan di PT. Geosciences Indonesia Servis adalah sebagai berikut:

$\mathrm{C} 1$ = Berdasarkan Gaji

$\mathrm{C} 2=$ Berdasarkan Absensi

C3 = Berdasarkan Rating Kedisiplinan

C4 = Berdasarkan Ratung Kejujuran

C5 $=$ Berdasarkan Inovatif

Penilaian terhadap $\mathrm{C} 1$ dan $\mathrm{C} 2$ menggunakan nilai yang asli / real kemudian untuk aspek C3, C4, C5 tersebut dengan cara memberi skor 1 (satu) sampai dengan 4 (empat). Adapun Interpretasi dari setiap nilai untung rating kinerja dan gaji adalah sebagai berikut :

- Nilai 1 berarti "Kurang Layak"

- Nilai 2 berarti "Cukup Baik/Layak"

- Nilai 3 berarti "Baik/Layak"

- Nilai 4 berarti "Sangat Baik/Layak"

Tabel 2. Keterangan bobot Kategori Penilaian

\begin{tabular}{cl}
\hline $\begin{array}{c}\text { Bobot } \\
\text { Penilaian }\end{array}$ & \multicolumn{1}{c}{$\begin{array}{c}\text { Kategori } \\
\text { Penilaian }\end{array}$} \\
\hline 1. & Kurang Layak \\
2. & Cukup Baik/Layak \\
3. & Baik/Layak \\
4. & Sangat Baik/Layak \\
\hline
\end{tabular}

\section{Simulasi Perhitungan Kinerja Karyawan dengan Metode SAW}

Langkah pertama menentukan kinerja karyawan menggunakan metode Simple 
Additive Weighting (SAW) adalah sebagai Berikut:

a. Menentukan fungsi benefit ( semakin tinggi nilai maka semakin diprioritaskan) atau fungsi cost (semakin rendah nilainya maka semakin baik) dari stiap kriteria pemilihan kinerja karyawan seperti terlihat pada table berikut:

\section{Tabel 3. Fungsi Kriteria Kinerja Karyawan}

\begin{tabular}{ccc}
\hline No & Kriteria & Fungsi \\
\hline 1. & Gaji & Cost $(-)$ \\
2. & Absensi & Benefit $(+)$ \\
3. & Kedisiplinan & Benefit $(+)$ \\
4 & Kejujuran & Benefit $(+)$ \\
5 & Inovatif & Benefit $(+)$ \\
\hline
\end{tabular}

b. Setelah menentukan fungsi kriteria dari penilaian kinerja karyawan selanjutnya membutuhkan sebuah data pembobotan yang di gunakan untuk melakukan sebuah perhitungan lanjutan, seperti pada table 4 sebagai berikut :

\section{Tabel 4. Pembobotan Kriteria Kinerja} Karyawan

\begin{tabular}{ccc}
\hline No & Kriteria & Bobot \\
\hline 1. & Gaji & $20 \%$ \\
2. & Absensi & $30 \%$ \\
3. & Kedisiplinan & $15 \%$ \\
4 & Kejujuran & $25 \%$ \\
5 & Inovatif & $10 \%$ \\
\hline
\end{tabular}

c. Dalam melakukan perhitungan mengunakan metode Simple Additive Weighting (SAW) adalah dengan mendeterminasikan namanama calon kandidat yang menjadi alternative, yaitu :
1. $\mathrm{A} 1=$ Latif
2. $\mathrm{A} 2=$ Hery
3. $\mathrm{A} 3=$ Alul
4. $\mathrm{A} 4=$ Kafid

d. Tahap selanjutnya dilakukan perhitungan nilai setiap alternatif dengan cara melakukan perkalian dari hasil nilai matriks normalisasi setiap alternative per kriteria dengan bobot per kriteria yang sudah di tentukan sebelumnya, Hasil perhitungan dapat dilihat pada table 5,6 dan 7 .

Tabel 5. Matriks Awal Nilai Alternatif Kandidat Kenaikan Jabatan

\begin{tabular}{cccccc}
\hline Alternatif & Gaji & Absensi & Disiplin & Kejujuran & Inovatif \\
\hline A1. & 5JT & 220 & 3 & 3 & 2 \\
A2. & 4JT & 210 & 4 & 4 & 3 \\
A3. & 3JT & 202 & 3 & 2 & 4 \\
A4. & 4JT & 200 & 3 & 3 & 3 \\
\hline
\end{tabular}

Dalam tabel 5, terdapat nilai awal dari setiap alternative kemudian di hitung menggunakan rumus sesuai dengan kriteria yang ada pada table 3 untuk mendapatkan nilai normalisasi :

Untuk Alternatif 1 ( A1 ) :

Gaji : MIN (GAJI) / 5 JT $=3 / 5=0.60$ Absen : $220 / \operatorname{MAX}($ Absen $)=220 / 220=1$ Disiplin : $3 / \operatorname{MAX}($ Disiplin $)=3 / 4=0.75$ Kejujuran : $3 /$ MAX (Kejujran $)=3 / 4=0.75$ Inovatif : $2 / \mathrm{MAX}($ Inovatif $)=2 / 4=0.5$

Alternatif 2 (A2) :

Gaji : MIN (GAJI) / 4 JT $=3 / 4=0.75$

Absen : 210/MAX(Absen $)=210 / 220=0.95$

Disiplin : 3 / MAX(Disiplin $)=3 / 4=0.75$

Kejujuran: 4/MAX(Kejujuran) $=4 / 4=1$

Inovatif : 2 / MAX(Inovatif $)=2 / 4=0.5$

Alternatif 3 (A3) :

Gaji : MIN (GAJI) / 4 JT $=3 / 4=0.75$

Absen : 202/MAX(Absen $)=202 / 220=0.91$

Disiplin : 3 / MAX(Disiplin $)=3 / 4=0.75$

Kejujuran: $4 / \operatorname{MAX}($ Kejujuran $)=2 / 4=0.5$ Inovatif : 2 / MAX(Inovatif $)=4 / 4=1$

Alternatif 4 (A4) :

Gaji : MIN (GAJI) / 4 JT $=4 / 4=1$

Absen : 202/MAX(Absen $)=200 / 220=0.90$

Disiplin : 3 / MAX(Disiplin $)=3 / 4=0.75$

Kejujuran: 4/MAX(Kejujuran)3/4=0.75

Inovatif $: 2 / \mathrm{MAX}($ Inovatif $)=3 / 4=0.75$ 
Masing-masing alternatif telah dihitung kemudian masukan kedalam table sebagai berikut :

Tabel 6. Matriks Awal Nilai Alternatif Setelah di Normalisasi

\begin{tabular}{cccccc}
\hline Alternatif & Gaji & Absensi & Disiplin & Kejujuran & Inovatif \\
\hline A1. & 0.60 & 1 & 0.75 & 0.75 & 0.5 \\
A2. & 0.75 & 0.95 & 0.75 & 1 & 0.5 \\
A3. & 0.75 & 0.91 & 0.75 & 0.5 & 1 \\
A4. & 1 & 0.90 & 0.75 & 0.75 & 0.75 \\
\hline
\end{tabular}

Dari nilai alternatif yang sudah ternormalisasi maka kemudian dilakukan perhitungan Preferensi dari setiap kriteria dengan bobot yang sudah di tentukan pada table 4, sebagai berikut :

Alternatif 1 (A1) :

$(0,60 * 20 \%)+(1 * 30 \%)+(0.75 * 15 \%)+(0,75 *$ $25 \%)+(0.5 * 10 \%)=0.76(76 \%)$

Alternatif 2 (A2) :

$(0,75 * 20 \%)+(0.95 * 30 \%)+(0.75 * 15 \%)+(1 *$ $25 \%)+(0.5 * 10 \%)=0.85(85 \%)$

Alternatif 3 (A3) :

$(0,75 * 20 \%)+(0.91 * 30 \%)+(0.75 * 15 \%)+(0$, $5 * 25 \%)+(1 * 10 \%)=0.76(75 \%)$

Alternatif 4 (A4) :

$(1 * 20 \%)+(0.90 * 30 \%)+(0.75 * 15 \%)+(0,75 *$ $25 \%)+(0.75 * 10 \%)=0.84(84 \%)$

Tabel 7. Matriks Hasil Akhir Nilai Alternatif

\begin{tabular}{ccc}
\hline Alternatif & Hasil & Ranking \\
\hline A1. & $0.76 / 76 \%$ & 3 \\
A2. & $0.85 / 85 \%$ & 1 \\
A3. & $0.75 / 75 \%$ & 4 \\
A4. & $0.84 / 84 \%$ & 2 \\
\hline
\end{tabular}

e. Berdasarkan simulasi di atas, maka karyawan yang mendapatkan ranking 1, berarti karyawan atau alternatif 2 (A2) mendapat prioritas nomor 1 untuk terpilih menjadi kandidat yang berhak naik jabatan.
Tampilan Layar Aplikasi SPK Kenaikan Jabatan Karyawan

Tampilan layar aplikasi Sistem Pendukung Keputusan Kenaikan Jabatan karyawan terdiri dari beberapa rancangan sebagai berikut :

\section{Tampilan Menu Login}

Tampilan layar ini digunakan untuk masuk kedalam aplikasi Sistem Pendukung Keputusan Kenaikan Jabatan di PT. Geosciences Indonesia Servis.

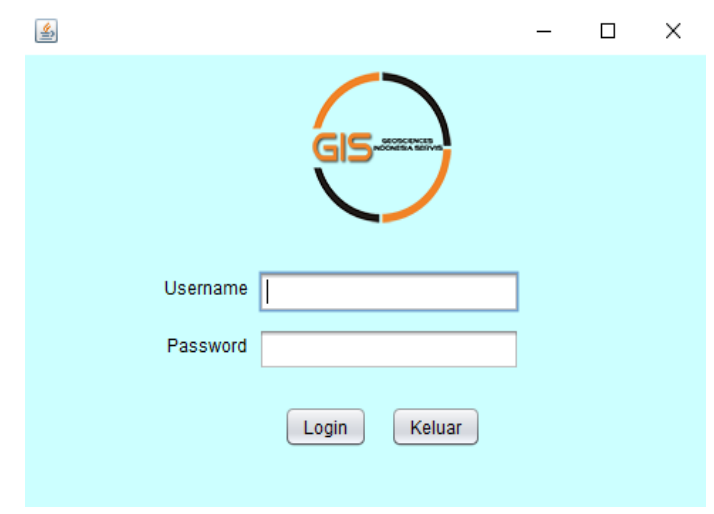

Gambar 1. Tampilan Menu Login

\section{Tampilan Menu Utama}

Tampilan Menu Utama ini digunakan untuk menampilkan menu data input data master, proses perhitungan, hitung kelayakan, dan laporan.

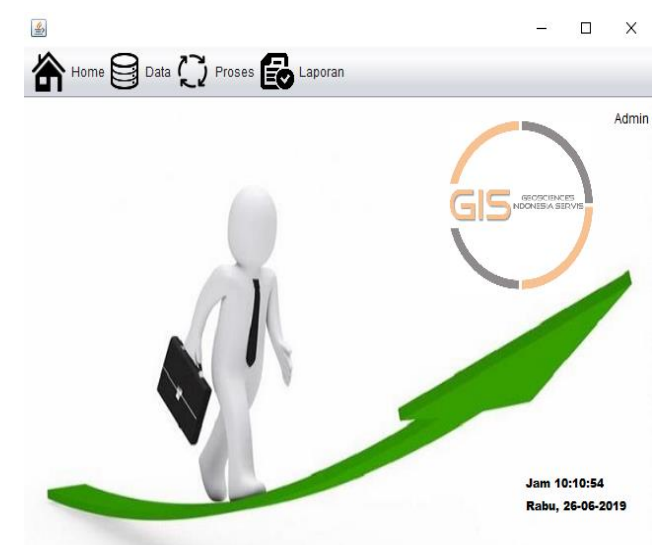

Gambar 2. Tampilan Menu Utama 


\section{Tampilan Data Karyawan}

Tampilan Data Karyawan ini digunakan untuk menginput, delete, ubah atau hapus data karyawan.

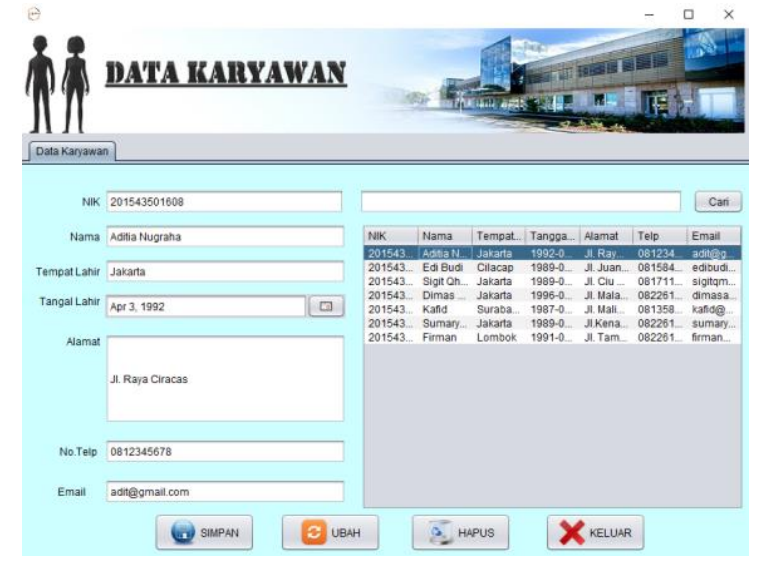

Gambar 3. Tampilan Data Karyawan

\section{Tampilan Data Jabatan}

Tampilan data jabatan digunakan untuk menampilkan interface entry, ubah dan hapus data jabatan

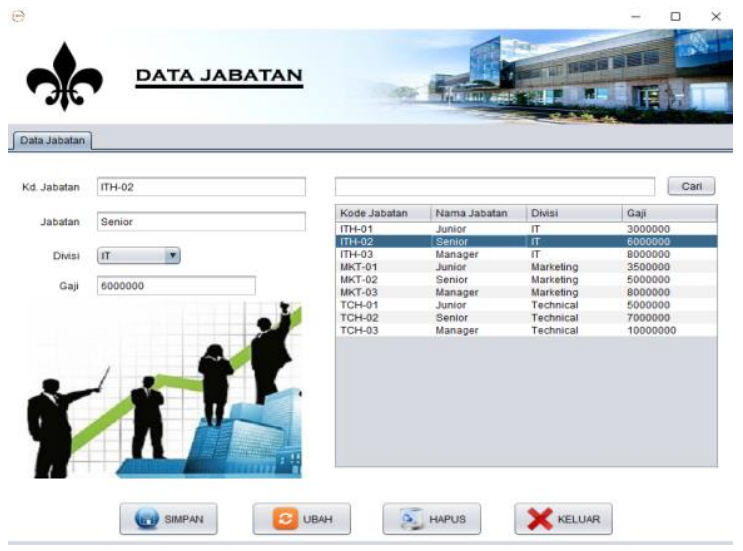

Gambar 4. Tampilan Data Jabatan

\section{Tampilan Data Absensi}

Tampilan data Absensi digunakan untuk input, ubah dan hapus data absensi yang telah di inputkan

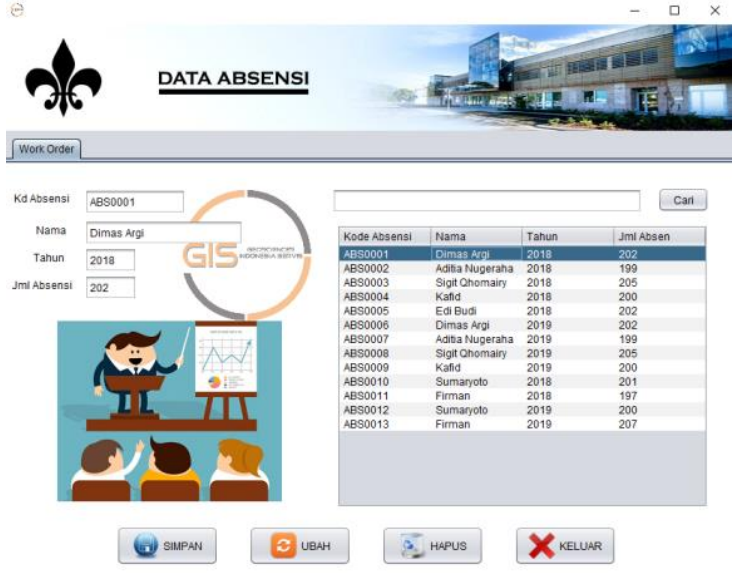

Gambar 5. Tampilan Data Absensi

\section{Tampilan Perhitungan}

Tampilan Perhitungan Kelayakan digunakan untuk menampilkan perhitungan data yang telah di input dengan metode Simple Additive Weighting.

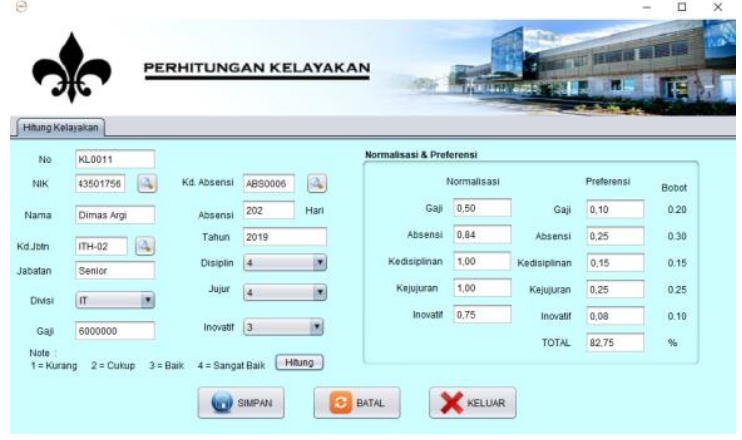

Gambar 6. Tampilan Perhitungan

Tampilan Cetak dan Hasil Laporan Karyawan, Jabatan, Absensi dan Hasil Perhitungan

Berisikan tentang cetak atau print laporan data karyawan, jabatan, absensi dan perhitungan serta hasil laporannya.

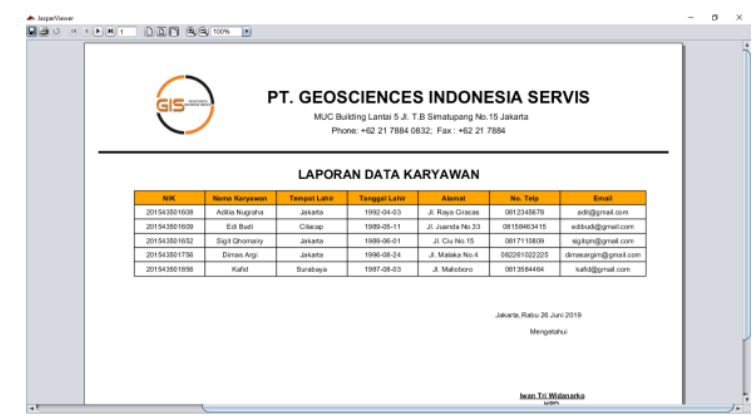

Gambar 7. Tampilan Hasil Cetak Data Karyawan 


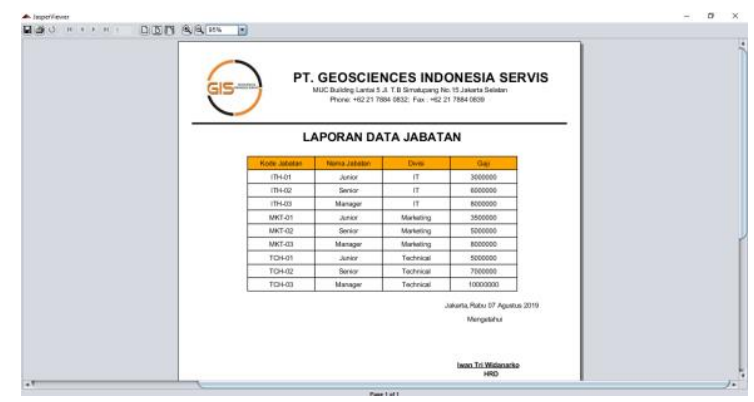

Gambar 8. Tampilan Hasil Cetak Data Jabatan

\% Laporan Kelayakan $\quad-\quad \square \quad \times$

LAPORAN PERHITUNGAN

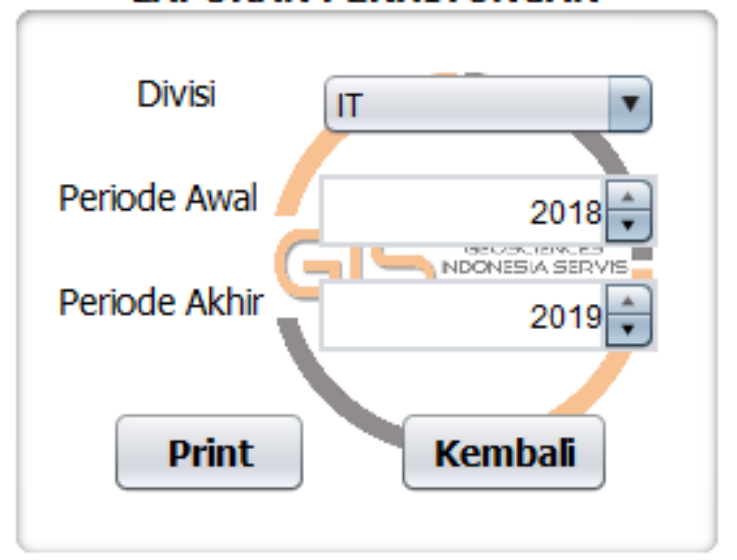

Gambar 9. Tampilan Cetak Data Perhitungan

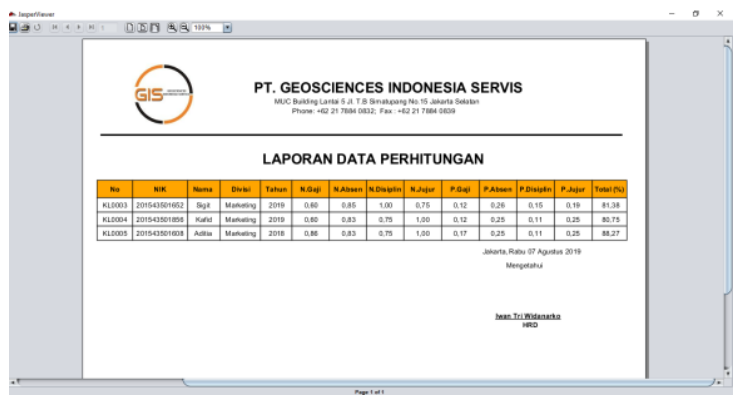

Gambar 10. Tampilan Hasil Cetak Data Karyawan

\section{SIMPULAN}

Dari pembahasan mengenai sistem pendukung keputusan untuk memilih karyawan yang berhak naik jabatan pada PT. Geosciences Indonesia servis, maka dapat dihasilkan beberapa kesimpulan sebagai berikut :
1. Sistem pendukung keputusan dengan menggunakan metode Sistem Additive Weighting (SAW) dapat mempermudah PT. Geosciences Indonesia Servis dalam menentukan karyawan yang layak naik jabatan.

2. Diharapkan Sistem Pendukung Keputusan ini dapat meminimalisir kesalahan serta mempermudah pencarian data. Dan tentunya menjadi lebih cepat dan efisien.

\section{DAFTAR PUSTAKA}

[1] Abdillah, Rahman.2017.Implementasi fuzzy simple additive weighting (SAW) sebagai pendukung keputusan pada beasiswa penelitian. Jurnal String Vol.2,No.1, hlm. 076-078

[2] Kustiyaningsih,Yeni.2011.Pemrogram an Basis Data Berbasis Web Menggunakan PHP dan MySQL. Yogykarta: Graha Ilmu

[3] Kusumadewi dan H. Purnomo, Aplikasi Logika Fuzzy Untuk Pendukung Keputusan, Edisi ke-2. Yogyakarta: Graha Ilmu, 2010.

[4] Marimin, M. 2010 .Aplikasi Teknik Pengambilan Keputusan Dalam Manajemen Rantai Pasok. Bogor: IPB Press.

[5] Mulyanto, Agus. 2009. Sistem Informasi Konsep dan Aplikasi. Yogyakarta: Pustaka Belajar.

[6] Muqtadir dan Purdianto. 2013. Sistem Pendukung Keputusan Kenaikan Jabatan Menggunakan Metode Profile Matching: Studi Kasus di PT. Industri Kemasan Semen Gresik. Jurnal Teknologi Informasi. ISSN: 19075022.

[7] Westriningsih. 2012. Membangun Aplikasi Bisnis dengan Netbeans 7. Yogyakarta: Andi 